\section{Duration of the breeding season on the reproductive performance of Anglo-Nubian goats during dry and rainy periods}

\author{
José Monteiro Almeida-Irmão,1 \\ Leopoldo Mayer Freitas Neto,2 \\ Marcelo Tigre Moura, 2 \\ Jairo Pereira Neves, ${ }^{3}$ \\ Paulo Fernandes Lima,2 \\ Marcos Antônio Lemos Oliveira² \\ 1Instituto Federal de Educação, Ciência e \\ Tecnologia de Pernambuco, Campus \\ Barreiros; 2Laboratório de Biotécnicas \\ Aplicadas à Reprodução, Departamento \\ de Medicina Veterinária da Universidade \\ Federal Rural de Pernambuco; \\ 3Laboratório de Reprodução Animal do \\ Departamento de Medicina Veterinária da \\ Faculdade de Agronomia e Medicina \\ Veterinária da Universidade de Brasília, \\ Brasil
}

\section{Abstract}

The study was aimed to evaluate the effect of breeding season (BS) duration on goat reproduction during dry (DS) and rainy (RS) periods. Females were kept $300 \mathrm{~m}$ apart from bucks for 60 days. Females were randomly distributed among BS groups of 25 (BS25), 35 (BS35), and 45 (BS45) days during DS and RS. All females cycled, except during BS45 in DS (95\%). The duration of BS did not affect estrous incidence during DS and RS. The percentage of females with two estrous was similar in RS (BS25: 30\%, BS35: 35\%, BS45: 35\%) and DS (BS25: 25\%, BS35: 30\%, BS45: 25\%). Three estrous were observed in BS35 and BS45 during RS (5\%). First estrous (FE) and second estrous (SE) were detected from days in BS25 (FE: 1-21, SE: 7-21), BS35 (FE: 1-23, SE: 6-27), and BS45 (FE:1-23, SE: 9-20) during RS. During DS, estrous were detected within days BS25 (FE: 1-17, SE: 6-23), BS35 (FE: 1-20, SE: 6-24), and BS45 (FE: 2-21, SE: 6-21). Pregnancy rates were similar in RS (BS25: 90\%, BS35: 95\%, BS45: 95\%) and DS (BS25: 75\%, BS35: 80\%, BS45: 75\%). In conclusion, goat BS can be shorten despite weather without any effect on reproduction.

\section{Introduction}

Goat production is performed worldwide and plays a major socioeconomic role, particularly in developing countries. Despite the successful adaptation of goats to most climate conditions and feeding systems, goat farming remains heterogeneous on overall management practices, usage of modern technologies, and production yields. In order to circumvent these limitations, simple practices such as synchronization of kidding delivery by controlled mating offers cost-effective returns. In order to concentrate offspring delivery in short periods of time, estrous synchronization by hormone-based protocols allows the preparation of female lots for controlled mating, artificial insemination or embryo transfer. ${ }^{1}$

The male effect is a natural process in small ruminants that stimulates and synchronizes estrous cycles in anestrous and cycling animals. ${ }^{2-4}$ The male effect is advantageous compared to hormone-based protocols due to its simplicity, low cost, limited animal handling and congruence with current demand for hormone-free livestock production systems. ${ }^{4}$

Much progress has been made on deciphering the male effect and its effect on female physiology, ${ }_{4}^{4}$ particularly in sheep. However, to our knowledge, fewer reports have been aimed to refine its use under commercial conditions. For practical usage, the male effect has been suggested using intervals of two to four weeks for the preconditioning period.5-7 Regarding the preconditioning distance, it has been suggested that a minimum distance of $1000 \mathrm{~m}$ between males and females should be practiced. ${ }^{7-8}$ The rationality of this long distance was in order to completely avoid any interaction between animals of opposite gender (physical, olfactory, auditive and hearing contact). Recent reports have demonstrated that even physical isolation is dispensable for male effect in sheep and goats.,9 Moreover, most reports have evaluated the effects of the male effect on ovulation, ${ }^{4}$ but pregnancy rates have not been described in most reports. Since recent discoveries on male effect have not been transferred to commercial breeding practices in small ruminants, a critical aspect of the procedure was revisited here. The aim of this work was to evaluate the effect of the duration of the breeding season during dry and rainy seasons on the reproductive performance of pluriparous goats.

\section{Materials and Methods}

This study was conducted in Sertânia, Pernambuco state, Brazil. The geographic coordinates are $9.107 .002 \mathrm{KmN}$ and 691.005 $\mathrm{KmE}$; altitude of $558 \mathrm{~m}$ and weather is semiarid with $25^{\circ} \mathrm{C}$ average annual temperature, $431 \mathrm{~mm}^{3}$ average annual rainfall, and rainy season from February to June.

One hundred and twenty pluriparous Anglo-
Correspondence: Marcos Antônio Lemos Oliveira Laboratório de Biotécnicas Aplicadas à Reprodução do Departamento de Medicina Veterinária da Universidade Federal Rural de Pernambuco. Av. Dom Manoel de Medeiros s/n, Dois Irmão, 52171-900 Recife, Pernambuco, Brasil.

Tel.Fax: +55.813 .3206415 .

E-mail: maloufrpe@uol.com.br.

Key words: biostimulation, caprine, buck effect, fertility, gestation.

Acknowledgments: FACEPE and CNPq for financial support of the study. M.T. Moura holds a CAPES fellowship and L.M. Freitas Neto holds a CNPq fellowship.

Contributions: JMA, PFL and MALO conceived the research; JMA, LMFN, PFL performed the research; JMA, LMFN, MTM, JPN, MALO analyzed the data, provided reagents and intellectual content; JMA, MTM, MALO wrote the paper.

Received for publication: 18 February 2014. Accepted for publication: 4 March 2014.

This work is licensed under a Creative Commons Attribution NonCommercial 3.0 License (CC BYNC 3.0).

(C) Copyright J.M. Almeida-Irmão et al., 2014 Licensee PAGEPress srl, Italy

Veterinary Science Development 2014; 4:5357 doi:10.4081/vsd.2014.5357

Nubian females were used in the study (24 to 60 months of age). On the day before the start of the experiments, females received numbered plastic rings, were weighed and evaluated for body condition scoring (BSC) as previously described. 10 The reproductive status of the females was evaluated by ultrasound, 11 and vaginoscopy exam adapted from cattle. 12

Three bucks (24 to 48 months of age) were kept in individual stalls before the experiment onset and fed with grass as described below and supplemented with $200 \mathrm{~g}$ of concentrated feed (Durancho®, Nutrição Animal, Pesqueira, Brazil) and $200 \mathrm{~g}$ of corn grain (Zea mays, L)/animal/day. Bucks were kept apart from females at a distance of $300 \mathrm{~m}$ without visual, olfactory or hearing contact for 60 days.

Bucks were submitted to andrologic examination the day before the experiment and were used in an 1:20 male to female ratio. ${ }^{13}$ When introduced into the female lot, bucks were marked with a mixture of grease and ink (4:1) around the sternum to facilitate identification of cycling females (bucks were re-marked with ink every 10 days). Mating events (females in estrous) were observed daily at $6.00 \mathrm{a} . \mathrm{m}$. and again at 4.00 p.m. for one hour by trained personnel. 
The DS was from September 9 to October 28, 2008 and the RS was from March 6 to April 19 of 2010. Breeding seasons (BS) had 25 (BS25), 35 (BS35) and 45 (BS45) days of duration, respectively. During the DS, females $(n=60)$ showed average body weight of 38.35 at BS25 $(\mathrm{n}=20), 38.90$ at BS35 $(\mathrm{n}=20)$ and $38.30 \mathrm{Kg}$ at BS45 $(n=20)$, and body condition scoring equivalent to 3.0. During the RS, female average body weight $(\mathrm{n}=60)$ was 37.35 at BS25 $(\mathrm{n}=20), 37.40$ at BS35 $(\mathrm{n}=20)$, and $37.25 \mathrm{Kg}$ at BS45 $(n=20)$ and body condition scoring equivalent to 3.0. Pregnancy diagnosis was determined by ultrasound examination on the 60 th day after the last mating of the BS, as previously described. ${ }^{11}$

The results were evaluated by descriptive statistical analysis, Student's T testing for comparing averages, chi-square for ratio comparison, and Fisher's test for comparing variances. Level of significance was $5 \%$.

\section{Results}

Females displayed one, two or three estrous throughout the experiment (Table 1). There was no influence of BS duration on number of estrous both in the DS and RS ( $\mathrm{P}>0.05)$. Estrous incidence was $100 \%$ at BS25, BS35 and BS45, except that $95 \%$ of the BS45 females cycled during the during the DS. These data do not show any influence of BS duration on the incidence of estrous in the DS or RS ( $\mathrm{P}>0.05)$.

The distribution of estrous events varied during each breeding season during both DS and RS (Table 2). Estrous were detected in the DS from day 1 until day 21 for the first estrous, from day 7 until day 21 for the second estrous in the BS25. At BS35, it varied from day 1 to day 23 for the first estrous and from day 6 to day 27 for the second estrous, and the third estrous occurred on the 24th day. At BS45, it varied from day 2 to day 21 for the first estrous and from day 6 to day 21 for the second estrous.

Pregnancy rates were obtained at the end of breeding seasons during DS and RS (Table 3). During the RS, pregnancy rates varied from 90 to $95 \%$, whereas during the DS it varied from 75 to $80 \%$. There was no effect of breeding season duration on overall pregnancy rates during the RS and DS $(\mathrm{P}>0.05)$.

\section{Discussion and Conclusions}

The high incidence of estrous behavior regardless of breeding season duration and weather conditions confirms the remarkable and profound consequences of the male effect on female reproductive physiology. According to several authors, the sudden introduction of

Table 1. Percentage of first, second and third estrous in Anglo-Nubian goats submitted to breeding season of different durations (BS25, BS35, BS45) during Dry (DS) and Rainy (RS) periods.

\begin{tabular}{|c|c|c|c|c|c|c|}
\hline \multirow[t]{2}{*}{ Estrous (\%) } & \multicolumn{3}{|c|}{ Rainy season } & \multicolumn{3}{|c|}{ Dry season } \\
\hline & BS25 & BS35 & BS45 & BS25 & BS35 & BS45 \\
\hline First & 70 & 60 & 60 & 75 & 70 & 70 \\
\hline Second & 30 & 35 & 35 & 25 & 30 & 25 \\
\hline Third & - & 5 & 5 & - & - & - \\
\hline Total & 100 & 100 & 100 & 100 & 100 & 95 \\
\hline
\end{tabular}

Table 2. Interval between estrous in Anglo-Nubian goats submitted to male effect in breeding seasons of different duration (BS25, BS35, BS45) during Rainy (RS) and Dry (DS) periods.

\begin{tabular}{|c|c|c|c|c|c|c|c|c|c|}
\hline Range & & estr & & & estr & & & estr & \\
\hline & Mn & Mx & Ave & Mn & Mx & Md & Mn & Mx & Ave \\
\hline Dry seas & & & & & & & & & \\
\hline BS25 & 1 & 21 & 7.05 & 7 & 21 & 13.40 & - & - & - \\
\hline BS35 & 1 & 23 & 6.00 & 6 & 27 & 12.50 & 24 & 24 & 24.0 \\
\hline BS45 & 1 & 23 & 7.90 & 9 & 20 & 12.40 & 30 & 30 & 30.0 \\
\hline Rainy se & & & & & & & & & \\
\hline BS25 & 1 & 17 & 7.35 & 6 & 23 & 14.40 & - & - & - \\
\hline BS35 & 1 & 20 & 6.85 & 6 & 24 & 11.62 & - & - & - \\
\hline BS45 & 2 & 21 & 6.36 & 6 & 21 & 10.37 & - & - & - \\
\hline Total & 1 & 23 & 6.91 & 6 & 27 & 12.44 & 24 & 30 & 27 \\
\hline
\end{tabular}

Mn, minimum; Mx, maximum; Ave, average.

Table 3. Pregnancy rates in the first, second and third estrous Anglo-Nubian goats submitted to breeding seasons of different duration (BS25, BS35, BS45) during Rainy (RS) and dry (DS) periods.

\begin{tabular}{|c|c|c|c|c|c|c|}
\hline \multirow{2}{*}{ Estrous (\%) } & \multicolumn{3}{|c|}{ Rainy season } & \multicolumn{3}{|c|}{ Dry season } \\
\hline & BS25 & BS35 & BS45 & BS25 & BS35 & BS45 \\
\hline First & 60 & 55 & 55 & 55 & 60 & 60 \\
\hline Second & 30 & 35 & 35 & 20 & 20 & 15 \\
\hline Third & - & 5 & 5 & - & - & - \\
\hline Total & 90 & 95 & 95 & 75 & 88 & 75 \\
\hline
\end{tabular}


a buck or ram into the midst of isolated females increases LH pulsatility and provokes a preovulatory $\mathrm{LH}$ peak stimulating final follicular development and ovulation.,2,5,14-17

Mating events are expected to be observed within an 15-25 day period after male introduction to the female herd.14,15,17,18 These results and the data described here support the hypothesis that females can exhibit from one to three estrous within an 35-day period, 17 since female goats have estrous cycle ranging from 18 and 22 days, 19 but estrous cycles of less than 17 days have been observed. ${ }^{1}$ Here, most female goats had one single estrous and only a small fraction exhibited three estrous during the DS (5\%), and a second estrous was observed within an average period of 12.44 days. A plausible explanation for this short cycle would be due to a premature regression of the corpus luteum, ${ }^{19}$ or insufficient secretion of $\mathrm{P} 4$ by corpus luteum with low luteal cell counts due to low-quality follicles. ${ }^{20}$ Thus, a low serum concentration of $\mathrm{P} 4$ would be insufficient to block a LH peak of the dominant follicle during the first follicular wave after the first ovulation.

More importantly, the first estrous induced by the male effect is accompanied by physiological estrous behavior and ovulation with fertilizing capacity. ${ }^{2}$ In accordance with this statement, in this study $55 \%$ to $60 \%$ of cycling females conceived in the first mating.

Pregnancy rates were similar between all breeding seasons, reinforcing the hypothesis that breeding seasons can be intensively shorten compared to previous recommendation of 45 to 60 days..$^{3,21,22}$ It has been recommended an 63-day breeding season for its implementation, and 49 days for subsequent breeding seasons. ${ }^{3}$ Moreover, the duration of breeding seasons was determined based upon the estrous cycle of 21 days in goats and the experience of the farmer on overall management practices. 3,22

Nutrition is a major factor on the reproductive performance of goats. Thus, it is important to note that the study took place under the semi-arid climate of northeast Brazil, similar to other tropical areas of the world were most of the goat population is found. These areas are predominantly characterized by limited disposability of quality forage, since both native vegetation and cultivated pastures hold low nutritional value, especially during the DS. The fact that pregnancy rates were similar during both DS and RS allows the assumption that the nutrition was not a confounding factor over the reproductive efficiency during the DS, due to forage supplementation with grass silage (Pennisetum purpureum, Schum).
In summary, the breeding season duration on RS and DS does not affect the reproductive performance of pluriparous female goats based upon estrous incidence and pregnancy rates. These findings highlight the potential of shortening goat breeding seasons to 25 days, allowing the reduction of investments on feeding supplementation and trained personnel for estrous detection and kidding delivery assistance.

\section{References}

1. Chemineau P. Effect on estrus and ovulation of exposing Creole goats to the male at three times of the year. J Reprod Fertil 1983;67:65-72.

2. Chemineau P. Possibilities for using bucks to stimulate ovarian and oestrous cycles in anovulatory goats. A review. Livest Prod Sci 1987;17:135-47.

3. Simplício AA, Salles HO, Santos DO, Azevedo HC. Manejo reprodutivo de caprinos e ovinos de corte em regiões tropicais. Sobral-CE: Embrapa Caprinos, 2001. Documento, $n^{0} 40$.

4. Delgadillo JA, Gelez H, Ungerfeld R, et al. The male effect in sheep and goatsrevisiting the dogmas. Behav Brain Res 2009;200:304-14.

5. Martin GB, Oldham CM, Cognie Y, Pearce DT. The physiological responses of anovulatory ewes to the introduction of ramsreview. Livest Prod Sci 1986;15:219-47.

6. Rosa HJD, Bryant MJ. The ram effect as a way of modifying the reproductive activity in the ewe. Small Rumin Res 2002;45:1-16.

7. Ungerfeld R, Forsberg M, Rubianes E. Overview of the response of anoestrous ewes to the ram effect. Reprod Fertil Dev 2004;16:479-90.

8. Pearce GP, Oldham CM. Importance of non-olfactory ram stimuli in mediating ram-induced ovulation in the ewe. J Reprod Fertil 1988;84:333-9.

9. Véliz FG, Poindron P, Malpaux B, Delgadillo JA. Maintaining contact with bucks does not induce refractoriness to the male effect in seasonally anestrous female goats. Anim Reprod Sci 2006;92:300-9.

10. Gonzalez-Stagnaro C. Control y manejo de los factores que afectam al comportamiento reproductivo de los pequeños rumiante em el mediotropical. In: International symposium on nuclear and related techiques in animal production and health. Proc
Viena Intertation Atomic Energy Agency, 1991. pp 405-421.

11. Santos MHB, Oliveira MAL, Moraes EPBX, et al. Diagnóstico de gestação por ultrasonografia de tempo real. In: Santos MHB, Oliveira MAL, Lima PF, eds. Diagnóstico de gestação na cabra e na ovelha. São Paulo: Varela; 2004. pp. 97-116.

12. Grunert E, Birgel EH, Vale WG. Semiologia do trato genital feminino. In: Patologia e clínica da reprodução dos animais mamíferos domésticos: ginecologia. São Paulo: Varela; 2005. pp 181-251.

13. Colégio Brasileiro de Reprodução Animal. Manual para exame e avaliação de sêmen animal. Belo Horizonte: CBRA; 1998. p. 49.

14. Shelton M. Influence of the presence of a male goat on the initiation of estrous cycling and ovulation of Angora does. $\mathrm{J}$ Anim Sci 1960;9:368-75.

15. Ott RS, Nelson DR, Hixon JE. Effects of presence of the male on initiation of estrous cycle activity of goats. Theriogenology 1980;13:183-90.

16. Chemineau P. Effects on a progestagen on buck-induced short ovarian cycles in the creole meat goat. Anim Reprod Sci 1985;9:87-94.

17. Lima SA, Costa AN, Reis JC, Pereira RJTA. Malle effect associated or not to cloprostenol in the induction and sychronization of estrous in Anglo-Nubian goats. Ciênc Vet Tróp 2000;3:102-10.

18. Luna-Orozco JR, Fernández IG, Gelez H, Delgadillo JA. Parity of female goats does not influence their estrous and ovulatory responses to the male effect. Anim Reprod Sci 2008;106:352-60.

19. Jainudeen MR, Wahid H, Hafez ESE. Ovinos e caprinos. In: Hafez ESE, Hafez B, eds. Reprodução Animal. São Paulo; Manole; 2004. pp 173-182.

20. Chemineau P, Pellicer-Rubio MT, Lassoued $\mathrm{N}$, et al. Male-induced short estrous and ovarian cycles in sheep and goats: a working hypothesis. Reprod Nutr Dev 2006;46: 417-29.

21. Medeiros LP, Girão RN, Girão ES, Pimentel JCM. Caprinos: Princípios básicos para sua exploração. Embrapa - Centro de Pesquisa Agropecuária do Meio Norte, pp.63-82 1994.

22. Oliveira LRS. Male effect associated breeding season on reproductive performance in the Angle-Nubian goats raised in the semi-arid regions of the State of Pernambuco. PhD dissertation. Universidade Federal Rural de Pernambuco, Recife, 2009. 